\title{
Fermentation Capacity of Saccharomyces cerevisiae Cultures
}

\author{
Elvira Maria Bezerra de Alencar*, Cristina Maria de Souza-Motta, Bruno Souza Walter, \\ Rejane Maria Pessoa Santos, Olga Martins Marques and Lusinete Aciole de Queiroz \\ Departamento de Micologia; Universidade Federal de Pernambuco; Recife - PE - Brasil
}

\begin{abstract}
This work aimed at the assessment of fermentative capacity of original diploid, monocellular haploid and recuperated diploid cultures of $S$. cerevisiae in sterilized sugar-cane wort. Twenty eight cultures were analyzed, four being original diploids (URM-4420, Itaiquara Ferment FIT, Lallemand Ferment FLA and Wild Ferment SEL); 12 monocellular haploids from original ones and 12 recuperated diploids from the monocells. The ethanol percentage ranged from 1.7 to $6.2 \%$ and the unfermentable reducing sugars from 0.45 to $0.50 \mathrm{~g} / 100 \mathrm{~mL}$. The highest ethanol percentages were produced by the monocellular cultures URM-MH3 (4.8\%) in $12 \mathrm{~h}$ and SEL-MH1 (6.2\%) in $24 \mathrm{~h}$, corresponding to the productivity values of 3.15 and $2.03 \mathrm{~g} . \mathrm{L}^{-1} \cdot \mathrm{h}^{-1}$, respectively. The recuperated diploids did not present detectable ethanol content by the method used. The results showed that depending on the physiological state of the yeasts, being in the diploid or monocellular haploid form, different percentages of ethanol could be produced.
\end{abstract}

Key-Words: Saccharomyces cerevisiae, monocellular, fermentation

\section{INTRODUCTION}

The word fermentation comes from the latin word "fervere", which means boiling. It was used by Pasteur to name microbiological actions in sugar substrata releasing great amount of gas, giving the impression of boiling. The agents responsible for this transformation were called "ferments" (Fulmer, 1930; Souza and Queiroz, 1995).

The alcoholic fermentation consists of the transformation of carbohydrates in ethanol and carbonic gas through the anaerobic metabolism; however, other substances such as glycerol and acetic acid are produced in smaller amounts (Cook, 1958; Conn and Stumpf, 1972; Stupiello and Horii, 1981; Scriban, 1985; Souza and Queiroz, 1995). The substratum used in alcoholic fermentation is highly variable and can be constituted by sugar products, such as sugar-cane broth, beet root, honey, molasses and fruits or amylaceous materials, such as starch grains, roots, tubercles and others (Cook, 1958; Jones et al., 1981; Lima et al., 1985; Scriban, 1985; Souza and Queiroz, 1995).

The microorganisms responsible for the alcoholic fermentation are yeasts, such as Saccharomyces, Schizosaccharomyces, Kluyveromyces, Brettanomyces, Kloeckera and Nadsonia sp. (Prescott and Dunn, 1959; Jones et al., 1981; Moraes, 1981; Lima et al., 1985; Evangelista, 1989; Souza and Queiroz, 1995).

The microorganism to be used in ethanol fermentation process should have specific well defined characteristics, such as ability to ferment carbohydrates with high performance, high fermentation speed, osmotolerance, tolerance to ethanol, ability to produce high concentrations of ethanol, tolerance to acid medium, high cellular viability for repeated recyclings, resistance to high temperatures and genetic stability of the

\footnotetext{
* Author for correspondence: elalencar@yahoo.com.br
} 
characteristics previously mentioned (Ferrari et al., 1980).

This work had the objective of characterizing original diploid, monocellular haploid and recuperated diploid cultures of $S$. cerevisiae, regarding their fermentative capacity.

\section{MATERIAL AND METHODS}

\section{Culture media}

For the fermentative assays, sterilized distilled water added to sugar-cane broth (1:1 ratio) was used after sterilization in at $120^{\circ} \mathrm{C}$ for 15 minutes.

\section{S. cerevisiae cultures}

The following cultures were used: URM-4420 (Micoteca do Departamento de Micologia, Universidade Federal de Pernambuco, Recife, PE); Itaiquara Ferment FIT (Usina Itaiquara do Açúcar e do Álcool, Vitória de Santo Antão, PE, from the fermented sugar-cane wort); Lallemand Ferment FLA (Destilaria São Pedro - Ribeirão, PE/Danstil 493 EDV from sugar-cane molasses) and Wild Ferment SEL (Destilaria São Pedro, Ribeirão, PE - from the sugar-cane broth).

\section{Monocellular haploid cultures}

After confirmation of purity, original diploid and monocellular haploid cultures of $S$. cereviseae were obtained. The original cultures of $S$. cereviseae were cultivated in Agar Gorodkowa medium for asci formation. From the cultures producing asci, microbial suspensions in $10 \mathrm{~mL}$ of sterilized distilled water were prepared. After being homogenized with a $1 \mathrm{~mL}$ sterilized pipette, successive dilutions up to a final concentration of $1: 100,000$, corresponding to a concentration of $10^{-}$ ${ }^{5}$ cells $/ \mathrm{mL}$ were prepared. Then, one aliquot was mounted on a glass slide and observed under microscope until appearance of a maximum of three cells, without budding, per field. After that $0.2 \mathrm{~mL}$ were taken and spread radially, in duplicate, with the aid of a Drigalski holder, on the surface of Agar Sabouraud medium plus yeast extract in Petri plates. The cultures were maintained at room temperature $\left(28 \pm 1^{\circ} \mathrm{C}\right)$ for $72 \mathrm{~h}$. From the four original cultures, 28 monocellular cultures, being 7 from URM-4420, 7 from Itaiquara Ferment, 7 from Lallemand Ferment and
7 from the Wild Ferment were obtained. The monocellular cultures were cultivated in Agar Sabouraud plus yeast extract and maintained at room temperature $\left(28 \pm 1^{\circ} \mathrm{C}\right)$ for $48 \mathrm{~h}$. After this period, the cultures were transferred to glass tubes with Agar Gorodkowa and Agar Potassium Acetate for the production of asci and maintained at room temperature $\left(28 \pm 1^{\circ} \mathrm{C}\right)$ for up to 15 days. Monocellular cultures stable at the haploid phase were selected following the criteria of Lodder (1970), Rose and Harrison (1987) and Walker (1998).

\section{Diploid recuperation}

Eighty four intercrossings among the 28 monocellular haploid cultures, 21 being from URM-4420, 21 from Itaiquara ferment, 21 from Lallemand ferment and 21 from the Wild ferment were performed.

The monocellular haploid cultures were placed on Agar Sabouraud plus yeast extract and kept at room temperature $\left(28 \pm 1^{\circ} \mathrm{C}\right)$ for $48 \mathrm{~h}$. Afterwards, equal amounts of paired cultures were inoculated into deep, straight grooves cut into the sporulation medium (Agar Gorodkowa and Agar Potassium Acetate), containing slanted tubes (Lodder, 1970). The cultures were kept at room temperature $\left(28 \pm 1^{\circ} \mathrm{C}\right)$ up to 30 days.

Taxonomic confirmation of original cultures, monocellular haploids and recuperated diploids All the cultures were confirmed according to the criteria adopted by Lodder (1970); Kreger-van Rij (1984); Kurtzman (1998); Barnett et al. (2000).

\section{Pre-inoculum preparation and medium for the fermentative assays}

All the cultures were placed on Agar Sabouraud plus yeast extract and kept at room temperature $\left(28 \pm 1^{\circ} \mathrm{C}\right)$ for $48 \mathrm{~h}$. Then, $100 \mathrm{~mL}$ microbial suspensions in the sterilized distilled water were prepared with a yeast concentration around to 1.2 x $10^{9}$ cells $/ \mathrm{mL}$ (Bier, 1992). For the fermentative assays, solutions of $150 \mathrm{~mL}$ of sterilized distilled water and sugar-cane broth (1:1), were autoclaved at $120^{\circ} \mathrm{C}$ for 15 minutes. $50 \mathrm{~mL}$ microbial suspensions used to inoculate $150 \mathrm{~mL}$ of the sugarcane wort contained in $250 \mathrm{~mL}$ Erlenmeyer's flasks and kept at room temperature $\left(28 \pm 1^{\circ} \mathrm{C}\right)$ for $24 \mathrm{~h}$. 
Brix, Total Reducing Sugars (TRS) and Unfermentable Reducing Sugars (URS)

The Brix was determined in a refractometer. To determine the TRS and URS, $1 \mathrm{~mL}$ of the supernatant was hydrolized with chloridic acid $(1: 2, \mathrm{v} / \mathrm{v})$ at $60^{\circ} \mathrm{C}$ for 20 minutes in a volumetric balloon of proper volume. After cooling to room temperature $\left(28^{\circ} \mathrm{C} \pm 1^{\circ} \mathrm{C}\right)$, it was neutralized with a $40 \% \mathrm{NaOH}$ solution and two drops of alcoholic solution of $1 \%$ phenolftalein as indicator. The content was adjusted with distilled water according to the capacity of the volumetric balloon and after homogenization $1 \mathrm{~mL}$ was transferred to Follin-Wu tubes. To this volume, $1 \mathrm{~mL}$ of the 3.5 dinitrisalicylic acid (DNSA) reagent was added (Miller, 1959), followed by boiling in a water bath for 15 minutes. The cooling was done with ice bath and the volume was adjusted to $12.5 \mathrm{~mL}$ with distilled water. After being homogenized, the absorbance was measured using a spectrophotometer (Spectronic 20D - Milton Roy Company) at 540nm (Souza and Queiroz, 1995).

\section{Determination of ethanol concentration}

The concentration of ethanol in the samples of fermented wort was determined using a DUJARDIN - SALLERON 359 ebulliometer and the measurements were taken at 12 and $24 \mathrm{~h}$ of fermentation. The ethanol productivity values were calculated by dividing the alcohol content by fermentation time, considering an $0.789 \mathrm{~g} / \mathrm{mL}$ density of ethanol at $20^{\circ} \mathrm{C}$.

\section{RESULTS AND DISCUSSION}

The initial values of Brix and TRS of the sterilized sugar-cane wort were $10.3 \%$ and $8.68 \%$, respectively. Table 1 shows the results of fermentation assays of original diploid and monocellular haploid cultures of $S$. cerevisiae in sterilized sugar-cane. The recuperated diploid cultures did not present detectable alcohol content by the method used. In a general way, the percentage of ethanol produced by the original diploid and monocellular haploid cultures changed, in $12 \mathrm{~h}$, from 1.7 to $4.8 \%$ and in $24 \mathrm{~h}$, from 5 to $6.2 \%$. The productivity changed from 1.12 to $3.15 \mathrm{~g} . \mathrm{L}^{-1} \cdot \mathrm{h}^{-1}$ in $12 \mathrm{~h}$ and from 1.64 to 2.03 g. $\mathrm{L}^{-1} \cdot \mathrm{h}^{-1}$ in $24 \mathrm{~h}$, meanwhile the URS changed from 0.45 to $0.50 \mathrm{~g} / 100 \mathrm{~mL}$ of sugar-cane broth.
From the original URM-4420 and the monocellular haploid cultures (URM-MH1, URMMH2 and URM-MH3), the original URM-4420 and the URM-MH1 produced the lowest percentage of ethanol $(1.7 \%)$ and values of productivity $\left(1.12 \mathrm{~g} \cdot \mathrm{L}^{-1} \cdot \mathrm{h}^{-1}\right)$ in $12 \mathrm{~h}$, and in $24 \mathrm{~h}$ (5\% and 1.64 g. $\left.\mathrm{L}^{-1} \cdot \mathrm{h}^{-1}\right)$. However, the highest percentage of ethanol $(4.8 \%)$ and values of productivity $\left(3.15 \mathrm{~g} . \mathrm{L}^{-1} \cdot \mathrm{h}^{-1}\right)$ in $12 \mathrm{~h}$, was produced by the URM-MH3 and in $24 \mathrm{~h}(5.8 \%$ and 1.9 g.L ${ }^{1} \cdot \mathrm{h}^{-1}$ ) by URM-MH1 and URM-MH3. The lowest amount of the URS $(0.46 \mathrm{~g} / 100 \mathrm{~mL})$ was obtained by the monocellular URM-MH3 and the highest amount $(0.5 \mathrm{~g} / 100 \mathrm{~mL})$ by the original culture URM-4420 (Table 1).

From the original Itaiquara Ferment and the monocellulars FIT-MH1, FIT-MH2 and FIT-MH3, the highest amount of ethanol $(4.2 \%)$ and values of productivity $\left(2.76 \mathrm{~g} \cdot \mathrm{L}^{-1} \cdot \mathrm{h}^{-1}\right)$ in $12 \mathrm{~h}$, was produced by the original Itaiquara Ferment and in $24 \mathrm{~h}$ $\left(5.4 \%\right.$ and 1.77 g.L $\left.\mathrm{L}^{-1} \cdot \mathrm{h}^{-1}\right)$ by the FIT-MH1. However, the lowest percentage of ethanol (2.4\%) and values of productivity $\left(1.57 \mathrm{~g} . \mathrm{L}^{-1} \cdot \mathrm{h}^{-1}\right)$ in $12 \mathrm{~h}$, were observed in the FIT-MH1 culture and in $24 \mathrm{~h}$ $\left(5.1 \%\right.$ and 1.67 g. $\left.\mathrm{L}^{-1} \cdot \mathrm{h}^{-1}\right)$ by FIT-MH2. The lowest URS value $(0.46 \mathrm{~g} / 100 \mathrm{~mL})$ was obtained by FITMH1 and the highest $(0.49 \mathrm{~g} / 100 \mathrm{~mL})$ on FIT-MH2 (Table 1).

From the original Lallemand Ferment and the monocellular cultures FLA-MH1, FLA-MH2 and FLA-MH3, the one that produced (in $12 \mathrm{~h}$ ), the lowest percentage of ethanol (1.7\%) and values of productivity $\left(1.12 \mathrm{~g} \cdot \mathrm{L}^{-1} \cdot \mathrm{h}^{-1}\right)$ was the original Lallemand Ferment, and in $24 \mathrm{~h}(5.4 \%$ and 1.77 g. $\left.\mathrm{L}^{-1} \cdot \mathrm{h}^{-1}\right)$ the original Lallemand Ferment, LAFMH1 and LAF-MH2. However, the highest percentage of ethanol $(4.7 \%)$ and values of productivity $\left(3.09 \mathrm{~g} . \mathrm{L}^{-1} \cdot \mathrm{h}^{-1}\right)$ in $12 \mathrm{~h}$, was produced by FLA-MH2, and in $24 \mathrm{~h}\left(5.6 \%\right.$ and $1.83 \mathrm{~g} . \mathrm{L}^{-1} \cdot \mathrm{h}^{-}$ $\left.{ }^{1}\right)$ by the FLA-MH3. The lowest value of URS $(0.45 \mathrm{~g} / 100 \mathrm{~mL})$ was observed at the FLA-MH2 and the highest $(0.5 \mathrm{~g} / 100 \mathrm{~mL})$ at the original Lallemand Ferment (Table 1).

From the original Wild Ferment and monocellular cultures SEL-MH1, SEL-MH2 and SEL-MH3, the highest percentage of ethanol (4.3\%) and values of productivity $\left(2.82 \mathrm{~g} . \mathrm{L}^{-1} \cdot \mathrm{h}^{-1}\right)$ in $12 \mathrm{~h}$, were produced by SEL-MH1 and in $24 \mathrm{~h}\left(6.2 \%\right.$ and $\left.2.03 \mathrm{~g} . \mathrm{L}^{-1} \cdot \mathrm{h}^{-1}\right)$ by the same culture. However, the lowest percentage of ethanol $(1.7 \%)$ and values of productivity $\left(1.12 \mathrm{~g} . \mathrm{L}^{-1} \cdot \mathrm{h}^{-1}\right)$ in $12 \mathrm{~h}$, were observed 
in the original Wild culture and in 24 hours $(5.6 \%$ and $\left.1.83 \mathrm{~g} . \mathrm{L}^{-1} \cdot \mathrm{h}^{-1}\right)$ in the SEL-MH2. The lowest value of URS $(0.45 \mathrm{~g} / 100 \mathrm{~mL})$ was observed in the SEL-MH1 and the highest value $(0.48 \mathrm{~g} / 100 \mathrm{~mL})$, in the original Wild Ferment, SEL-MH2 and SELMH3 (Table 1).

In a general way, the highest percentage of ethanol $(4.8 \%)$ in $12 \mathrm{~h}$ was produced by the URM-MH3 and in $24 \mathrm{~h}(6.2 \%)$, by the SEL-MH1 culture. However, the lowest percentage of ethanol (1.7\%) were obtained in $12 \mathrm{~h}$, by original URM-4420, original Lallemand Ferment, original Wild Ferment and URM-MH1 and in $24 \mathrm{~h}(5 \%)$, by the original URM-4420.

The highest values of productivity $\left(3.15 \mathrm{~g} . \mathrm{L}^{-1} \cdot \mathrm{h}^{-1}\right)$ and $\left(2.03 \mathrm{~g} \cdot \mathrm{L}^{-1} \cdot \mathrm{h}^{-1}\right)$ in 12 and $24 \mathrm{~h}$ were found in the URM-MH3 and SEL-MH1 cultures, respectively. However, the lowest values (1.12 g. $\mathrm{L}^{-1} \cdot \mathrm{h}^{-1}$ ) were observed in $12 \mathrm{~h}$, in the original URM-4420, original Lallemand Ferment, original Wild Ferment and URM-MH1, and in $24 \mathrm{~h}(1.64$ g. $\left.\mathrm{L}^{-1} \cdot \mathrm{h}^{-1}\right)$ in the original URM-4420.

The lowest values of URS $(0.45 \mathrm{~g} / 100 \mathrm{~mL})$ were observed in the FLA-MH2 and SEL-MH1 and the highest $(0.5 \mathrm{~g} / 100 \mathrm{~mL})$ in the original URM-4420 and original Lallemand Ferment.

The results showed that from the same percentage of Brix, different percentages of ethanol were produced. However, the best results in percentage of ethanol and productivity were observed in $12 \mathrm{~h}$, by the monocellular haploid culture URM-MH3 $\left(4.8 \%, 3.15 \mathrm{~g} . \mathrm{L}^{-1} \cdot \mathrm{h}^{-1}\right)$ and in $24 \mathrm{~h}$, by the SELMH1 $\left(6.2 \%, 2.03\right.$ g.L $\left.\mathrm{L}^{-1} \cdot \mathrm{h}^{-1}\right)$.

The results showed that depending on the physiological state of the yeasts, being in the diploid or monocellular haploid form, different percentages of ethanol could be produced and consequently different values of productivity could be obtained.

Reports mentioning that different samples of the same species could have different physiological characteristics, among them the fermentative capacity, have been described by Jones et al.
(1981); Kreger-van Rij (1984); Souza and Queiroz, 1995.

Ribeiro and Horii (1999), studying three strains of $S$. cerevisiae to evaluate their performance on ethanol fermentation, observed that the best productivity $\left(3.40 \mathrm{~g} . \mathrm{L}^{-1} \cdot \mathrm{h}^{-1}\right)$ was presented by the IZ-987 flocculent strain.

Gomes et al. (2004) used three strains of $S$. cerevisiae to study the optimization of the fermentative process, aiming to evaluate the kinetic parameters of fermentation and observed that the UFMG-A 1007 strain presented better values regarding productivity; however, the UFMG-A 907 strain presented the best results regarding fermentative parameters.

Silva-Filho et al. (2005) studying the optimization of the fermentative process, used 14 strains of $S$. cerevisiae, being three commercial, one industrial and ten from Culture Collection, and observed that the residual sugar was less than $1 \mathrm{~g} / \mathrm{L}$ for all the cultures. Most of the strains presented elevated productivity with fermentation efficiency above $90 \%$.

Cletto and Mutton (1995), evaluating the effect of addition of two lineages of $S$. cerevisiae to sugarcane broth, aimed to analyze the dynamics of fermentative process and observed significant differences in ethanol production.

In literature, works focusing on ethanolic fermentation using monocellular haploid cultures of $S$. cerevisiae, are not found.

In a general way, the alcohol industry does not take into account the physiological state in which the yeast is found, working in the sugar-cane juice medium or wort of molasses, just giving priority to the productivity of the fermentative process.

As this work demonstrated, the diploid form or monocellular haploid of $S$. cerevisiae affected the ethanol productivity values and probably the oscillations obtained in the values of this parameter in the alcoholic fermentation processes, be on small or large scale, were due to the physiological conditions in which the yeast was found. 
Table 1 - Results of fermentative assays of original diploid and monocellular haploid (MH) cultures of S.cerevisiae in sterilized sugar-cane wort.

\begin{tabular}{|c|c|c|c|c|}
\hline Culture & Time (h) & Ethanol (\%) & $\begin{array}{c}\text { Productivity } \\
\left(\text { g. } \mathrm{L}^{-1} . \mathrm{h}^{-1}\right)\end{array}$ & $\begin{array}{c}\text { URS after 24h } \\
(\mathrm{g} / 100 \mathrm{~mL})\end{array}$ \\
\hline \multirow{3}{*}{$\begin{array}{l}\text { URM- } 4420 \\
\text { (Original) }\end{array}$} & 0 & 0 & 0 & \multirow[b]{3}{*}{0,50} \\
\hline & 12 & 1,70 & 1,12 & \\
\hline & 24 & 5,00 & 1,64 & \\
\hline \multirow{3}{*}{$\begin{array}{l}\text { URM-4420 } \\
\text { (URM - MH1) }\end{array}$} & 0 & 0 & 0 & \multirow[b]{3}{*}{0,48} \\
\hline & 12 & 1,70 & 1,12 & \\
\hline & 24 & 5,80 & 1,90 & \\
\hline \multirow{3}{*}{$\begin{array}{l}\text { URM-4420 } \\
\text { (URM - MH2) }\end{array}$} & 0 & 0 & 0 & \multirow[b]{3}{*}{0,47} \\
\hline & 12 & 3,90 & 2,56 & \\
\hline & 24 & 5,60 & 1,83 & \\
\hline \multirow{3}{*}{$\begin{array}{l}\text { URM-4420 } \\
\text { (URM - MH3) }\end{array}$} & 0 & 0 & 0 & \multirow[b]{3}{*}{0,46} \\
\hline & 12 & 4,80 & 3,15 & \\
\hline & 24 & 5,80 & 1,90 & \\
\hline \multirow{3}{*}{$\begin{array}{l}\text { Itaiquara Ferment } \\
\text { (Original) }\end{array}$} & 0 & 0 & 0 & \multirow[b]{3}{*}{0,48} \\
\hline & 12 & 4,20 & 2,76 & \\
\hline & 24 & 5,20 & 1,71 & \\
\hline \multirow{3}{*}{$\begin{array}{l}\text { Itaiquara Ferment } \\
\text { (FIT - MH1) }\end{array}$} & 0 & 0 & 0 & \multirow[b]{3}{*}{0,46} \\
\hline & 12 & 2,40 & 1,57 & \\
\hline & 24 & 5,40 & 1,77 & \\
\hline \multirow{3}{*}{$\begin{array}{l}\text { Itaiquara Ferment } \\
(\mathrm{FIT}-\mathrm{MH} 2)\end{array}$} & 0 & 0 & 0 & \multirow[b]{3}{*}{0,49} \\
\hline & 12 & 2,60 & 1,71 & \\
\hline & 24 & 5,10 & 1,67 & \\
\hline \multirow{3}{*}{$\begin{array}{l}\text { Itaiquara Ferment } \\
(\mathrm{FIT}-\mathrm{MH} 3)\end{array}$} & 0 & 0 & 0 & \multirow[b]{3}{*}{0,47} \\
\hline & 12 & 3,00 & 1,97 & \\
\hline & 24 & 5,20 & 1,71 & \\
\hline \multirow{3}{*}{$\begin{array}{l}\text { Lallemand Ferment } \\
\text { (Original) }\end{array}$} & 0 & 0 & 0 & \multirow[b]{3}{*}{0,50} \\
\hline & 12 & 1,70 & 1,12 & \\
\hline & 24 & 5,40 & 1,77 & \\
\hline \multirow{3}{*}{$\begin{array}{l}\text { Lallemand Ferment } \\
\text { (FLA - MH1) }\end{array}$} & 0 & 0 & 0 & \multirow[b]{3}{*}{0,48} \\
\hline & 12 & 3,70 & 2,42 & \\
\hline & 24 & 5,40 & 1,77 & \\
\hline \multirow{3}{*}{$\begin{array}{l}\text { Lallemand Ferment } \\
\text { (FLA - MH2) }\end{array}$} & 0 & 0 & 0 & \multirow[b]{3}{*}{0,45} \\
\hline & 12 & 4,70 & 3,09 & \\
\hline & 24 & 5,40 & 1,77 & \\
\hline & 0 & 0 & 0 & \\
\hline $\begin{array}{l}\text { Lallemand Ferment } \\
\text { (FLA - MH3) }\end{array}$ & 12 & 4,30 & 2,82 & \\
\hline & 24 & 5,60 & 1,83 & 0,46 \\
\hline & 0 & 0 & 0 & \\
\hline $\begin{array}{l}\text { Wild Ferment } \\
\text { (Original) }\end{array}$ & 12 & 1,70 & 1,12 & \\
\hline & 24 & 6,00 & 1,97 & 0,47 \\
\hline & 0 & 0 & 0 & \\
\hline $\begin{array}{l}\text { Wild Ferment } \\
\text { (SFI - MH1) }\end{array}$ & 12 & 4,30 & 2,82 & \\
\hline & 24 & 6,20 & 2,03 & 0,45 \\
\hline & 0 & 0 & 0 & \\
\hline Wild Ferment & 12 & 3,80 & 2,50 & \\
\hline$(\mathrm{SEL}-\mathrm{MH} 2)$ & 24 & 5,60 & 1,83 & 0,48 \\
\hline & 0 & 0 & 0 & \\
\hline Wild Ferment & 12 & 3,70 & 2,42 & \\
\hline (SEL - MH3) & 24 & 5,80 & 1,90 & 0,48 \\
\hline
\end{tabular}

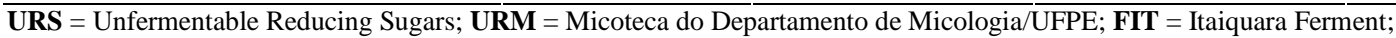

FLA = Lallemand Ferment; $\mathbf{S E L}=$ Wild Ferment.

\section{ACKNOWLEDGEMENTS}

To Destilaria São Pedro, represented by Ernesto Gonçalves Pereira Lima Neto, Margarete César
Resende Pereira Lima and Rejane Maria Pessoa Santos, by providing the original cultures of the ferments Itaiquara, Lallemand, and Wild and by the supervision during the fermentative assays. 


\section{RESUMO}

Este trabalho teve como objetivo avaliar culturas de $S$. cerevisiae diplóides originais, haplóides monocelulares e diplóides recuperados, quanto à capacidade de fermentar em mosto de cana-deaçúcar esterilizado. Vinte e oito culturas foram analisadas, sendo 4 diplóides originais (URM-4420, Fermento Itaiquara FIT, Fermento Lallemand FLA e Fermento Selvagem SEL); 12 haplóides monocelulares provenientes das originais e 12 diplóides recuperados a partir das monocelulares. $\mathrm{O}$ percentual de etanol produzido variou de $1,70 \%$ a 6,20\% e os açúcares redutores infermentescíveis de $0,45 \mathrm{~g} / 100 \mathrm{~mL}$ a $0,50 \mathrm{~g} / 100 \mathrm{~mL}$. Os maiores percentuais de etanol foram produzidos pelas culturas haplóides monocelulares URM-MH3 $(4,80 \%)$, em 12 horas e SEL-MH1 (6,20\%), em 24 horas, correspondendo a valores de produtividade $3,15 \mathrm{~g} . \mathrm{L}^{-1} \cdot \mathrm{h}^{-1}$ e $2,03 \mathrm{~g} \cdot \mathrm{L}^{-1} \cdot \mathrm{h}^{-1}$, respectivamente. Os diplóides recuperados não apresentaram teores de etanol detectáveis pelo método utilizado. Os resultados mostram que, dependendo do estado fisiológico das leveduras, seja na forma diplóide ou haplóide monocelular, podem ser produzidos diferentes percentuais de etanol.

\section{REFERENCES}

Barnett, J. A.; Payne, R. W.; Yarrow, D. (2000), Yeast: Characteristics and Identification. $2^{a}$ edição. 1002p.

Bier, O. (1992), Microbiologia e Imunologia. 27 Edição. São Paulo. Melhoramentos. p. 930-931.

Cleto, F. V. G.; Mutton, M. J. R. (1995), Influência de dois tipos de leveduras, do tratamento ácido e da adição de fubá de milho sobre o desenvolvimento do processo fermentativo e qualidade final do destilado. STAB. Açúcar, álcool e subprodutos. Piracicaba, 13(3).

Cook, A. H. (1958), The Chemistry and Biology of Yeasts. New York: Academic press, 763p.

Conn, E. E.; Stumpf, P. K. (1972), Manual de Bioquímica. São Paulo: Editora Edgard Blucher Ltda, 420p.

Evangelista, J. (1989), Tecnologia de Alimentos. Rio de Janeiro. Livraria Atheneu, 652p.

Ferrari, S. E.;Lopes, J. J. C.; Leme, J. R. A.; Oliveira, E. R. (1980), Industrial efficiency of alcohol fermentation: The comparative study. In: International Sympos of the Álcohol Fuels Technology. Proceedings. 4, p. 139-141.

Fulmer, E. I. (1930), The chemical approach to problems of fermentation. Industrial and Engineering Chemistry, 22(11), p. 148-150.
Gomes, F. C. O.; Silva, C. L. C.; Mendes, M. M.; Oliveira, E. S.; Rosa, C. A. (2004), Utilização de linhagens selecionadas de Saccharomyces cerevisiae para a produção de cachaça artesanal: Estudos dos parâmetros que influenciam a qualidade do produto. IV Congresso Brasileiro de Micologia, Ouro Preto MG, p.90.

Jones, R.P.; Pamment, N.; Greenfield, D.P.F. (1981), Alcohol Fermentation by Yeasts: The Effect of Environmental and other Variables. Process Biochemistry, p. 42-49.

Kurtzman, C. P. (1998), Yeast systematics - from phenotype to genotype. Food Tecnology and Biotecnology, .3(4), p.261-266.

Kreger-van Rij, N. J. W. (1984), The Yeasts: A Taxonomic Study. 3 Ed. Amsterdan: Elsevier, 1091p.

Lima, U. A.; Aquarone, E.; Borzani, W. (1985), Biotecnologia, Tecnologia das Fermentações. Ed. Edgard Blücher, 1. 285p.

Lodder, J. (1970), The Yeast: A taxonomic study. Oxford: North Holand Publishing Company. 1385p.

Miller, G. L. (1959), Use of dinitrosalicylic acid reagente for determination of reducing sugar. Analytical Chemistry, 31(3) p. 426-428.

Moraes, J. O. F. (1981), Fermentação Alcoólica. Curso de Especialização do Álcool-ITEP. Recife.

Prescott, S. C.; Dunn, C. G. (1959), Industrial Microbiology. New York: McGraw. Hill Book. 945p.

Ribeiro, C. A.; Horii, J. (1999), Potencialidades de linhagens de levedura Saccharomyces cerevisiae para a fermentação do caldo de cana. Scientia Agrícola, 56(2), p.255-263.

Rose, H. A.; Harrison, J. S. (1987), The Yeast. $2^{\mathrm{a}}$ edição. USA: Academic Press. 1, 423p.

Silva-Filho, E. A.; Santos, S. K. B.; Resende, A. M.; Morais, J. O. F.; Morais-Jr, M. A. Simões, D. A. (2005), Yeast population dynamics of industrial fuelethanol fermentation process assessed by PCRfingerprinting. Antonie van Leeuwenhoek, 88, p.1323.

Souza, C. M.; Queiroz, L. A. (1995), Flocculation and fermentation capacity of strains of Saccharomyces stored at Mycotheca-URM I. Boletin Micológico, 10(1-2): 89-95.

Scriban, R.(1985), Biotecnologia. São Paulo: Manole. $488 \mathrm{p}$.

Stupiello, J. P., Horii, J. (1981), Condução da fermentação alcoólica. Departamento de Tecnologia Rural - ESALQ, 4, n. 17.

Walker, G. M. (1998), Yeast Physiology and Biotechnology. Jonh Wiley and Sons Ltd. England, 350p.

Received: May 25, 2006;

Revised: June 22, 2007; Accepted: October 28, 2008 